This is the author's final, peer-reviewed manuscript as accepted for publication. The publisher-formatted version may be available through the publisher's web site or your institution's library.

\title{
The good, the bad, and the ugly: divorced mothers' experiences with coparenting
}

Melinda Stafford Markham, Marilyn Coleman

\section{How to cite this manuscript}

If you make reference to this version of the manuscript, use the following information:

Markham, M. S., \& Coleman, M. (2012). The good, the bad, and the ugly: Divorced mothers' experiences with coparenting. Retrieved from http://krex.ksu.edu

\section{Published Version Information}

Citation: Markham, M. S., \& Coleman, M. (2012). The good, the bad, and the ugly: Divorced mothers' experiences with coparenting. Family Relations, 61(4), 586-600.

Copyright: $\odot 2012$ by the National Council on Family Relations

Digital Object Identifier (DOI): doi:10.1111/j.1741-3729.2012.00718.x

Publisher's Link: http://onlinelibrary.wiley.com/doi/10.1111/j.17413729.2012.00718.x/abstract

This item was retrieved from the K-State Research Exchange (K-REx), the institutional repository of Kansas State University. K-REx is available at http://krex.ksu.edu 
Running head: DIVORCED MOTHERS' EXPERIENCES WITH COPARENTING

The Good, the Bad, and the Ugly:

Divorced Mothers’ Experiences with Coparenting 


\begin{abstract}
This study produces a grounded theory of how 20 predominantly White, well-educated women experienced sharing physical custody of their children with their former partners after divorce or separation. Three patterns of coparenting were identified in the data: continuously contentious, always amicable, and bad to better. Five negative factors and three positive factors that influenced mothers' coparenting relationships were identified. The type of relationship women had with their ex-partners was related to how they shared custody of their children (e.g., how they exchanged their children). The findings of this study suggest that shared physical custody relationships are dynamic and can vary greatly.
\end{abstract}

Key Words: coparenting, divorce, shared custody, grounded theory 
The Good, the Bad, and the Ugly: Divorced Mothers’ Experiences with Coparenting Although the divorce rate is lower than it has been since 1970 (Tejada-Vera \& Sutton, 2010), the number of first marriages that end in divorce remains around $40 \%$ (National Center for Health Statistics, 2002). Because many who divorce are parents, approximately 1.1 million children each year experience their parents’ divorce (Kreider, 2007). When parents divorce, shared legal custody is the legal presumption of judges in most states, but children tend to reside most of the time with their mothers (Cancian \& Meyer, 1998). In the past, divorced fathers were generally considered minimally involved in raising children after divorce, but that is changing; divorced parents more frequently share both legal and physical custody of children (Melli, Brown, \& Cancian, 1997). The purpose of this exploratory study was to investigate divorced and separated mothers’ experiences sharing physical custody of their children.

\section{Divorce}

There is a large body of research on divorce, much of which addresses issues of how divorce affects children (e.g., Johnston, 1995), fathers’ involvement after divorce (e.g., Minton \& Pasley, 1996), and how divorced partners coparent (e.g., Markham, Ganong, \& Coleman, 2007). Most divorce researchers have either used cross-sectional designs, primarily surveys, or they have relied on large secondary data sets (e.g., National Survey of Families and Households) to examine relationships between variables (e.g., Kim \& McKenry, 2002). These studies, however, provide snapshots of coparenting and have shed little light on the process of coparenting.

Although mothers are typically the primary parent, divorce researchers have seldom focused on them. This may be due to perceptions that women's mothering behaviors do not change after divorce; their involvement with children is similar to when they were married (Maccoby, Buchanan, Mnookin, \& Dornbusch, 1993). Father involvement, however, has tended 
to change after divorce (Minton \& Pasley, 1996), and scholars have been intrigued with how it changes and how these changes affect children. When investigators have studied the effects of divorce on mothers, they have tended to focus on the economic consequences of divorce (e.g., Sayer, 2006), role changes that occur after divorce (e.g., Arditti \& Madden-Derdich, 1995), mothers’ psychological well-being (e.g., Kim \& McKenry, 2002), and coparenting issues (e.g., Markham et al., 2007). Because most children reside primarily with their mother after divorce, there is much more research on mothers with sole custody than on those who share physical custody. Although increasing numbers of parents share custody of their children (Cancian \& Meyer, 1998), we still know little about how divorced parents negotiate this process.

Shared custody. Legal custody decisions are supposedly “gender-neutral” and decided with the "best interests of the child" in mind (Maccoby, Depner, \& Mnookin, 1990); mothers are no longer assigned sole custody of their children simply because of their role as mother (Demo \& Fine, 2009). Scholars have viewed fathers as increasingly important in their children's lives, and by the 1980s, the courts responded by interpreting the "best interests of the child" to mean continual contact with both parents after divorce (Maccoby et al., 1990). This interpretation was based in part on findings from two major studies (Hetherington, Cox, \& Cox, 1978; Wallerstein \& Kelly, 1980) reporting that children who lived with their mothers were better adjusted when they also maintained contact with their fathers. As a result, it became increasingly common for courts to award shared legal and physical custody to divorcing parents (Maccoby et al., 1990). In 2010, 47 states plus the District of Columbia had statutes authorizing the awarding of shared legal and physical custody if it was in the best interests of the child (Elrod \& Spector, 2011). Unfortunately, data on shared physical custody have not been collected by the National Center for Health Statistics since 1995 (Cork \& Voss, 2006). According to Cancian and Meyer 
(1998), however, between 1986 and 1994 the number of former partners in Wisconsin who opted to share physical custody doubled from $7 \%$ to $14.2 \%$. Although some decisions went through the courts, most custody arrangements were decided by the parents outside of court. These parents tended to bargain in "the shadow of the law" (Mnookin \& Kornhauser, 1979) meaning that although their decisions were made outside the legal system, they were influenced by the statutes governing their state (Kelly, 1994). So, as family laws change and shared physical custody becomes the legal presumption, it is likely that even more parents will opt for this arrangement. Parents decide to share physical custody for a number of reasons, including valuing the continuing presence of the other parent for the child (Lacroix, 2006) and providing relief from childrearing responsibilities for mothers in the paid labor force (Juby, Le Bourdais, \& MarcilGratton, 2005).

Although shared physical custody is a relatively new legal option, researchers have begun to explore some aspects of it, mostly focusing on comparing parents with shared physical custody with those who choose sole custody (e.g., Cancian \& Meyer, 1998), as well as on how custody arrangements affect child outcomes (e.g., Bauserman, 2002). Data from these studies indicate that divorced parents who share physical custody have higher incomes (Cancian \& Meyer, 1998), higher education levels (Juby et al., 2005), and smaller family sizes (Ellis, 2000) than those with sole custody arrangements. Additionally, fathers who share physical custody are likely to have flexible work schedules (Ellis, 2000); mothers are more likely to have a career and be invested in matters outside the home (Ellis, 2000; Juby et al., 2005).

In general, shared physical custody has been found to be beneficial to children and parents (see Bauserman, 2002, for a review). Parents reported less conflict and more cooperative relationships during the divorce process and less current conflict than those with sole custody 
arrangements. Mothers who shared physical custody also perceived their former partners as more supportive and understanding of their needs and reported having more respect for their former partners’ parenting abilities than did mothers with sole custody (Shiller, 1986). Of course, we cannot assume that shared custody was the cause of their good relationship. These parents may have shared physical custody because they already had a good relationship. Finally, mothers with shared physical custody were significantly less likely than sole custody mothers to report feeling overwhelmed (13\% with shared physical, 40\% with sole custody; Pearson \& Thoennes, 1990).

There are several limitations to the research on shared custody arrangements. The early research was criticized for small samples (Johnston, 1995), primarily from California (Pruett \& Hoganbruen, 1998). These studies also were conducted during a time when sharing physical custody was "less fashionable” (Steinman, 1981, p. 406) and parents interviewed were highly motivated to make shared custody work (Steinman, 1981). The findings from these studies, therefore, may no longer be relevant (Cancian \& Meyer, 1998).

Most recent research on shared physical custody has focused on predictors of custodial arrangements (e.g., Cancian \& Meyer, 1998) and how these arrangements affect children’s wellbeing (e.g., Bauserman, 2002). The scope of these studies, however, has been narrow and was not conducted within the broader realm of women's experiences. Research determining the number of people sharing physical custody, how they differ from those with sole custody, and the ways in which custody arrangements affect children provides little insight into mothers’ experiences sharing physical custody.

\section{The Present Study}

The purpose of this study was to explore the processes by which women who are divorced or separated share physical custody of their children. The investigation was guided by 
the following question: What processes underlie the experiences of divorced or separated mothers who are sharing physical custody of children with a former partner?

\section{Methods}

Grounded theory procedures were used to develop an integrated set of concepts that provide a theoretical explanation of mothers’ experiences sharing physical custody after separation. Data collection and analyses are integrated processes and, thus, data gathering, analysis, and theorizing were conducted simultaneously (Corbin \& Strauss, 2008).

Hypotheses were not developed in advance so that theory could be developed inductively from the data. Because grounded theorists view phenomena as continually changing and seek to examine processes (Corbin \& Strauss, 2008), the method is appropriate for examining how physical custody of a child is shared after separation.

\section{Data Collection}

Twenty women who fit the following criteria were recruited: (a) were divorced or separated from the fathers of their children, (b) their oldest child was 12-years-old or younger (age 12 was chosen because it was believed that younger children would require more coparenting involvement), and (c) they had both shared legal and physical custody arrangements. Shared physical custody was operationalized as between 50-50 and 33-67 (i.e., 33\% of time with one parent, $67 \%$ of time with other parent) division of childcare as identified by the mother. This was determined by taking the percentage of days each parent had custody of the child(ren) over a 2-week period (e.g., 8 out of 14 days $=57 \%$ ).

Mothers were recruited from a court-ordered parenting education program for divorcing parents, through flyers posted in public locations, and by snowball sampling. The recruitment material explained inclusion criteria, basic information about the study, the amount of 
compensation, and information about how to contact the first author. When interested mothers called or emailed, they were screened for inclusion criteria. If a mother met all criteria, an interview was scheduled. Eleven women who did not meet the criteria were not interviewed. All 20 women who agreed to be interviewed participated in at least one interview.

The 20 women in the sample were between the ages of 26 and 49 (M = 33.85 years; see Table 1); all lived in two Midwestern states. Nineteen were White/European American, one was African American. All participants had graduated from high school, 40\% attended some college or had an Associate’s degree, 35\% had Bachelor's degrees, and 25\% had postgraduate degrees. The time the women had lived with their ex-partners ranged from 2 to 17 years $(\mathrm{M}=6.88$ years), and they had been separated from 6 months to 12 years $(\mathrm{M}=3.01$ years $)$. The women's children ranged from 21 months to 12 years $(M=6.27$ years $)$. All participants shared physical custody, but the arrangements varied.

Each mother was interviewed at a time when her children were not present. Interviews lasted between 45 minutes and 2 hours and were digitally recorded. Eleven mothers were interviewed face-to-face, and nine were interviewed by phone; phone interviews were conducted because the first author moved out of state. Eleven mothers were interviewed more than once to clarify points raised in earlier interviews and to ask questions regarding issues that arose during data analysis. Our interpretations of the coparenting types were also verbally shared with 16 participants (11 of whom participated in a follow-up interview) in order to validate the data analysis. We were unable to schedule four mothers for follow-up interviews. For example, after explaining the three types of coparenting relationships we had identified to one mother in a follow-up interview, she reported that she had a bad to better relationship, which was congruent with our interpretation. "It is different now than when we first separated. He has realized that our 
conversations need to be solely based on the children and not on my life. Now our conversations stick to decision making about the children” (13). Participant ID numbers that correspond to Table 1 are included in parentheses following each quotation.

The interviews focused on participants’ perceptions of their experience of sharing physical custody with their former partners after separation. An unstructured interview guide served as a framework, and the interviews were conversational; follow-up questions were used to probe deeper into the experience. Relevant topics of discussion included women's thoughts about childrearing and being a mother, their relationship with former partners and with their children, and sharing physical custody in general. At the end of the interview, participants were given an opportunity to offer any additional information that they felt was relevant. They were then asked several demographic questions. Participants were paid \$10 for their participation.

\section{Data Analysis}

Data were transcribed verbatim into text files using Microsoft Word. Data analysis began following the first interview and continued throughout the remainder of data collection. QSR NVivo version 8.0 was used to aid in the process of data analysis.

Data were analyzed using constant comparisons; pieces of data were compared for similarities and differences (Corbin \& Strauss, 2008). Incidents that were similar were grouped together into a category and were given a conceptual label. Constant comparisons were conducted to differentiate one category from another and to identify dimensions of the categories (Corbin \& Strauss, 2008). With each addition of new data, categories were added and modified as needed. Connections were then made between the identified categories. For instance, we examined connections between reasons for sharing physical custody, financial concerns, perceptions of ex-partners’ parenting behaviors, and coparenting conflict. 
Theoretical memos were written during the first coding session and continued until the end of the study. As the research progressed, the memos became more elaborate and integrated (Corbin \& Strauss, 2008), enabled us to think about the data and how concepts were related to one another, and were used to record developing ideas about codes, categories, and the theory.

Theoretical sampling is defined as "sampling on the basis of concepts derived from data" (Corbin \& Strauss, 2008, p. 65). In order to employ theoretical sampling, we looked for situations that would contribute to a deeper understanding of the categories, variations within the categories, and relationships between concepts (Corbin \& Strauss, 2008). The women had differing shared custody arrangements (i.e., the amount of time differed), the ages of the children varied considerably, and single as well as remarried women were in the sample. We were able to examine whether or not these conditions affected the experience of sharing physical custody. Data were gathered until theoretical saturation was met, that is, the point at which all categories are well developed and additional data did not provide new insights (Corbin \& Strauss, 2008).

\section{Results}

The purpose of this study was to explore the processes by which women who are divorced or separated share physical custody of their children with their former partners. Three patterns of coparenting comprised the experience of sharing physical custody. A number of factors influenced these coparenting types, some of which were positive (e.g., believing the father was a responsible parent) and others were negative (e.g., financial concerns).

\section{Coparenting Types}

The coparenting typology was constructed based on mothers' descriptions of their relationships with their former partners from the time of separation until the time of the interview, and they exemplify the variations in shared custody coparenting relationships. The 
first coparenting type identified was continuously contentious. The 9 mothers in these relationships reported having conflictual relationships with their ex-partners from the time of separation to the present. In the 4 always amicable relationships, mothers reported consistently getting along with their ex-partners from the time of separation until the time of the interview. Bad to better relationships were those 7 in which coparenting was contentious at the time of separation but greatly improved over time. At the time of the interviews, these women's relationships resembled those of the always amicable women.

Continuously contentious. Several negative factors contributed to continuously contentious coparenting relationships including the mother's perception of her ex-partner's parenting abilities, financial concerns, control or abuse by the ex-partner, the inability of the expartner to separate marital issues from the coparenting relationship, and the mother not wanting to share physical custody. One mother described her relationship as: “...very tense...There’s still a lot of anger on both sides” (14).

Father is irresponsible parent. All mothers with continuously contentious relationships reported differences in parenting styles and voiced concerns about how their ex-partners were raising the children. Parenting practices that concerned the mothers varied greatly and included putting children in harmful situations, not bathing the children, not disciplining, and having no rules and routines. One mother complained: "My home is very structured. His home is not. We have routines, we have bedtime. They don't have any of that. They all sleep in the living room on the floor watching TV" (12). Another woman said, "She comes back, and she’s a filthy mess and obviously hasn't had a bath all weekend" (3).

Some mothers with serious concerns about their children's safety, described the difficulty of not being able to control what their children were exposed to in their ex-partners' homes. A 
mother of a 4-year-old said, “It’s very stressful because his dad drinks, and I'm concerned about him when he’s at his house” (20). Another mother explained,

I feel guilty when I have to send them over there and I can’t protect them and I don’t know what's going on... He’s really not that stable for me to be letting [them go to him], but he's their dad until they get hurt, and emotional abuse doesn’t count (8).

Four of the nine continuously contentious mothers explained that their ex-partners had been uninvolved parents when they were married, so sharing physical custody was difficult.

I remember at the beginning he’d call me, “Well how do I give her a bath? How do I feed her? What do I feed her?” He didn’t know how to do anything! Because he had refused to do it when we were together. But then, all of a sudden, he’s going to be super dad? So, on the phone, I'm walking him through how to feed her, what to feed her, how to give her a bath. That's really scary (3).

It was especially difficult for continuously contentious mothers to share custody with ex-partners who were uninvolved during the marriage; they did not believe they were responsible parents.

Money is a source of conflict. All mothers in continuously contentious relationships cited financial issues that negatively affected their coparenting relationships. One mother who paid both child support and maintenance to her ex-partner was frustrated because he was unemployed. “He’s not working at all, and he’s not seeking employment...He’s not financially responsible and doesn’t seem to feel any obligation to support his kids financially” (19). Four mothers said that they did not receive owed child support, and five others reported not receiving payment for expenses that were supposed to be split (e.g., medical bills, school lunches). A mother whose expartner was legally bound to pay $\$ 100$ per month in child support, cover her son’s insurance, and pay for half of day care said, “He stopped paying insurance, he hasn’t covered daycare in almost 
2 years, and he stopped paying child support as of February of this past year. So, we're going back to court to change that” (20). For these mothers, money was an overarching issue that negated the development of a positive coparenting relationship.

Personal issues not kept separate from parenting relationship. Four mothers perceived that their ex-partners were in great pain because of the divorce. Instead of focusing on their children and setting aside past relationship issues, these men continued to focus on their romantic relationship or personal feelings toward the mother. One mother described such an ex-partner. I mean she [daughter] has parents who can’t even get along, you know, and I just think that's not right...He needs to...not look at what went [wrong in our relationship], but to step up to the plate for her, and he can't seem to be able to do that (18).

When ex-partners were unable to set aside their personal issues with each other and focus on parenting the children, the coparenting relationship suffered.

Controlling ex-partner. All continuously contentious mothers reported instances of physical and verbal abuse, controlling behavior, or substance abuse during the marriage.

[My son's] been in therapy since he was 3-years-old. It's documented that [my son has] made reports to his therapists about his father's physical abuse toward him, and I made reports about verbal. One reason I left is because I don't have to go in and scoop [my son] up and protect him because of [my ex-partner's] anger (8).

The controlling behavior did not stop when the marriage ended and manifested in many different ways. A mother, separated from her partner for 3 years said,

When we separated he wanted to be super dad and he wanted her, but he knew it would kill me if I couldn't have her. That's how he knew he could get to me was through 
her...He came in fighting, and he was mad, and in his mind he was going to get full custody, and he was going to take her away from me (3).

A mother whose son has a medical condition believed her ex-partner was keeping important information from her. "We were both going to each [doctor's appointment], but recently that changed. He makes one appointment, and I make the next one. Only one parent is there for each appointment. That's very stressful because he doesn't tell me anything” (20). No matter what form the controlling behavior took, it was apparent that it harmed the coparenting relationship.

Mother did not want shared custody. Eight of the continuously contentious women had initially wanted sole custody of their children and said that shared physical custody arrangements were decided by the court $(n=5)$ or their ex-partners $(n=3)$ wanted shared custody. Women who were influenced by their ex-partners agreed to share custody for different reasons. One mother explained that her husband lied about how flexible he would be regarding custody. When we decided we were going to get a divorce, he said, "Even if this is what we have in writing, if she wants to spend more time with you, then so be it. It doesn't matter.” So, there are lots of things he's lied about just so he could get what he wanted (16).

Five women who did not want shared physical custody were either told by their lawyers or the court that they would have to do so.

It wasn't my choice. I was fighting for 100\% custody, and he would get visitation every other weekend. I'm going with what the judge said and making the best of the situation. I didn’t think that transferring her around during the week was a positive for her. I was striving for the every other weekend. Even if it was three weekends a month - that way the lack of structure wouldn't interfere with schooling and everything else (14). 
One continuously contentious mother did not fit this pattern. She wanted shared custody so her husband would keep the children while she worked. When he objected, she became upset.

He basically told me...he's not the babysitter, he is their father, and he's not going to babysit them anymore. So, I basically couldn’t take any extra on-call shifts this month, so I'm out 500 bucks...He has not followed through on his end of the bargain (8).

For the eight other continuously contentious women, shared custody was not their preference.

Always amicable. The four mothers with always amicable relationships had none of the negative factors experienced by the mothers in continuously contentious relationships. Instead, they believed their ex-partners were good parents, reported that money was not a source of conflict, and had opted to share physical custody. One mother described her always amicable relationship. "I would say we have a pretty good relationship. I really would...For the most part we get along very well and are really pretty similar to when we were married” (11).

Father is responsible parent. Always amicable mothers believed their ex-partners were living up to or exceeding their expectations as responsible fathers. One mother who had been the "primary" parent during the marriage and her ex-partner had been uninvolved in caring for the daughter said their coparenting relationship was positively affected when her ex-partner exceeded her expectations. "I didn’t expect that much out of him at that point...He turned out to be a better father than I had anticipated so that's been a pleasant surprise” (11). Although a few differences in parenting styles were reported, the ex-partners were deemed to be generally good parents, so the differences were not identified as major concerns. "We actually complement each other very well...He’s not what I consider very emotionally available... To me that's not that huge of an issue. They're more playmates, buddies. I'm more doing laundry or cooking dinner or whatever when [my son’s] around” (17). 
Money not a source of conflict. Although always amicable mothers were not more financially stable than mothers in the other two patterns, financial concerns did not affect coparenting. Two women, who did not receive child support but split expenses 50/50 with their ex-partners, believed this was working out well. One explained that her child's relationship with his father was more important than money.

I can’t imagine that just because my husband wasn’t able to financially contribute to [my son]... that I would take that [his relationship with his father] away from [my son]. Because he's really bonded to his dad; he deserves to have that relationship with him (2). Two mothers received what they perceived as adequate child support from their expartners. One who received \$545 per month said,

He pays me a decent amount of child support so I pretty much pay for anything that she needs...According to the divorce decree we were supposed to share medical expenses or anything like that, but because he pays for her insurance, I usually just pick up whatever’s left on the bill...When she was a little bit younger, if I needed help with something [financially] I would ask him, and he would help me (11).

Mother chose to share physical custody. All four women with always amicable relationships chose shared physical custody because they believed both parents deserved equal access to their children. One woman said, "I felt that she needed more time with her dad, but we needed to split the time evenly so that we had...the same amount of time together.” (7) These mothers believed that sharing custody was the right thing to do for their children.

Bad to better. The seven mothers with bad to better relationships had chosen shared custody, but ex-partners' feelings about one another got in the way. After a rocky start, however, they all reported that the relationship changed for the better. These mothers believed that their 
ex-partners were good parents and money was not a source of conflict. One mother described her relationship. "I think it’s getting better, getting easier. At the beginning it was just outrageous, and it’s definitely starting to get more normalized” (1).

Mother chose to share physical custody. Like the always amicable women, all the bad to better mothers wanted shared custody. One woman said, "So I told him that I wanted to be as fair as I could, and I felt like he was entitled to see them just as much as I was” (13).

Personal issues not kept separate from parenting relationship. All of the bad to better ex-partners were originally unable to coparent amicably because of ex-partners’ feelings toward one another. One mother who believed her ex-partner was upset about the divorce explained, “The first year or so everything was a struggle, but it was more like his revenge to me. He knew that if he would fight me about any little problem it would upset me” (13). One mother whose ex-partner had an affair explained, "I thought I would hate him forever in the beginning. I was so angry for what he did that I tried to get back at him, but that didn’t work” (4).

Choosing to change the relationship for the children's sake. Although ex-partners with bad to better relationships originally allowed their feelings about one another to negatively affect their coparenting, at some point, they realized this was not beneficial and made a conscious effort to change the relationship for the sake of their children. Two of the bad to better mothers were able to recount a specific event that contributed to their resolution with their ex-partners.

His dad's suicide made him kind of open up his eyes to a lot of things that he had done. That was the moment where we both were like, "You know what, we just forgive each other for everything that happened, and we're just going to start over and be good friends for the sake of our kids” (4).

For the other five bad to better mothers, the changes were more gradual. One said, 
I think always keeping [my son] at the focus of what I was trying to do as a person, as a parent you have to let some of that go. And since it's been working so far, I have no reason to rock the boat. Anything that I would do to be vengeful against my ex wouldn’t do anything but damage my son...I've let a lot of that anger go (15).

Father is responsible parent. Although four bad to better mothers did not initially agree with their ex-partners’ parenting styles, they were able to negotiate and increase the consistency between the two households. Despite some remaining differences at the time of the interviews, the bad to better mothers believed their ex-partners were good parents. For example, one mother said, “First of all, I have 100\% trust in my ex-husband’s parenting. If I didn’t, I wouldn’t allow my children to be with him as much. So I trust that he’s a good father” (4).

The other three bad to better mothers perceived few differences in parenting styles and reported that they believed their ex-partners were good parents. One said, "I'd say we both have similar thoughts about how to raise her" (10).

Money not a source of conflict. Four of the seven bad to better women said that money did not currently cause relationship conflict, but that it did earlier. Because their relationships had improved, they were able to communicate and come to an agreement on financial matters.

If ever I come in a bind and I need like money or stuff like that, he will always [help me]. Our friendship’s only evolved in the last 4 months. Before that, it was just pretty horrible. I couldn't go to him for anything without getting yelled at...Our son wears glasses, and I think he needs them for school, but [my ex-husband] sees it as a medical expense. We fought for about 3 months on it, and I finally gave up and just said, "I'll pay for them.” But now it's a little different, and he pays half of it (5). 
The other three bad to better mothers also reported that their ex-partners helped them financially when needed. One explained, "If I need something I can call him and ask him, and he’ll usually help me out” (13).

Although their relationships were bad initially, the mothers and their ex-partners put forth a conscious effort to set aside their differences. Once they did this, their relationships improved and they were able to share custody in a manner similar to the always amicable mothers.

\section{Processes by Which Women Shared Custody}

The type of relationship the women had with their ex-partners was related to how they communicated, dealt with differences in parenting styles, and exchanged children.

\section{Continuously contentious}

Communication. Continuously contentious mothers limited direct in person or phone communication with their ex-partners. They used alternate ways including email and texting.

Even though we have been apart for a year, we have not reached that place yet to where we can effectively communicate. I basically use email to communicate with him just because I can track it. He likes to use text messages. Actual verbal communication over the telephone or in person is very awkward and tense (14).

Three mothers were unable to communicate directly with their ex-partners in any form. One said, “We're just not on any terms. They’re not good, they’re not bad, there's just no terms. We don’t talk” (6). One woman who was unable to directly talk with her ex-partner sent messages through her mother in order to coparent. “And especially holidays, we really work with each other on that through my mom so she [daughter] gets to go both places” (18).

Dealing with differences in parenting styles. Continuously contentious mothers reported numerous differences in parenting styles but did not raise concerns with their ex-husbands 
because of their contentious communication. Unable to talk about their parenting concerns, they did one of two things to make sure their children were well cared for. Four explained differences in house rules to their children. One mother said, “I just explain, 'Well this is Mom’s and Mom has different rules than Dad has. We have to live by Mom’s rules when at Mom’s house'” (12).

Four did not address the issue with either their children or their ex-partners, but raised their children how they deemed to be proper when the children were with them. "I take care of her my way at my house and try to let go of his house because I can't control it. So I try to make sure she gets what I think she needs at my house” (14).

Exchanging child. Continuously contentious women described purposively limiting the interaction they had with their ex-partners when transferring the children from one home to the other. Two mothers exchanged their children solely through their children’s school or daycare. One parent dropped the children off in the morning and the other parent picked them up in the afternoon. Two other mothers described exchanges that took place at either their home or their ex-partners' homes, but they did not see each other during the exchanges. "He pulls up and he honks, and I just let them out the front door” (6).

Two mothers had protection orders against their ex-spouses, one for stalking and one for trespassing. To exchange their children in person, they were required to do so in public. "We exchanged at [a gas station] because we had to do it in a public place” (3). She went on to say:

So we'd have a few words there as long as there's not an issue. If some issue comes up, we cannot communicate verbally. It's the little things, “Here’s her backpack. She has the sniffles.” Whatever, just the small things. But if there’s an issue, we text or email (3).

\section{Always Amicable and Bad to Better}


Communication. Unlike the continuously contentious mothers, the always amicable and bad to better women were able to communicate well and often with their ex-partners. One always amicable mother said, "We talk daily” (2). A bad to better woman related, "Me and him we talk on the phone daily or more times per day just about anything and everything” (5).

All always amicable women and two bad to better mothers reported talking about issues related to their children but also about unrelated matters. One always amicable mother said, I talk to him pretty much about anything. Like I mentioned, he’s breaking up with his fiancée, and I’ve always kind of been there for him and kind of been a support for him. So he’s told me all about that, and I listen and give him advice. And sometimes I'll tell him things. Like I said, we get along pretty good, we really do (11).

Five of the seven bad to better mothers communicated with their ex-partner only about issues related to their children. These women found that once they limited their conversations to child related topics, they were able to coparent more effectively. "We try to just talk about the kids because if we talk about anything other than that then one of us will feel tension” (13).

Unlike the continuously contentious mothers, the always amicable and bad to better women were not restricted to indirect means of communicating. These mothers communicated with their ex-husbands in multiple ways. Mothers who had good relationships with their expartners, also engaged in more activities with them. Two reported they spent holidays together. “So Thanksgiving he came over to my sister's house and ate, and my brothers and everybody were over there so he still participates with my family a lot” (4).

Dealing with differences in parenting styles. Although most always amicable and bad to better mothers reported that they and their ex-partners parent their children similarly, some differences existed. When differences in parenting were identified by the always amicable and 
bad to better mothers, they dealt with them differently from the women in the continuously contentious pattern. Eight mothers (two always amicable and six bad to better) communicated directly. One always amicable mother said, "I just tell him that I have concerns and explain to him what my feelings are about it, and he expresses his” (7).

Two always amicable and one bad to better mother did not discuss concerns regarding differences in parenting styles with their ex-partners. One mother explained why.

At this point, I don't want to be seen as critical of [my ex-husband] because I want him to feel really confident, like he’s a great dad. And, you know, he really is. He’s very engaged. He spends a lot of time playing with [my son]. I mean he has his cranky moments, but on the whole, I think he’s a really great dad (17).

Exchanging child. Unlike the continuously contentious women who deliberately limited interaction with their ex-partners when exchanging the children, women in the always amicable or bad to better groups exchanged their children in ways they described as convenient for them. Mothers who exchanged children in person talked to their ex-partners. "He comes over to where I live, drives in the driveway, I go out there and I talk to him, and we transfer the kids that way and then sometimes I'll go to his house and get them” (5). Unlike the continuously contentious mothers, these women made no attempt to limit interaction with ex-partners.

\section{Discussion}

This study focuses on the experiences of divorced or separated mothers who share physical custody of their children with former partners, and expands our limited knowledge of processes related to shared custody. Coparenting relationships were categorized into three types (continuously contentious, always amicable, and bad to better), and a variety of both positive 
factors (e.g., mother choosing to share physical custody) and negative factors (e.g., a controlling ex-partner) contributed to this typology (see Figure 1).

It is evident from the mothers we interviewed that shared custody arrangements can vary considerably. What may be surprising is the level of animosity that accompanies shared custody, at least from some mothers’ perceptions. Although Bauserman (2002) reported that parents who share custody report less conflict than those with sole custody, nearly half the mothers in this study continue to have conflictual relationships with their ex-partners and seven others originally had conflictual relationships that are now more positive. Conversations with these women negate the notion that shared physical custody insures cooperative, less conflictual relationships.

A number of issues influence coparenting. For example, mothers’ perceptions of fathers’ parenting abilities influence coparenting, especially in continuously contentious relationships. Differences in parenting styles, concerns for children's safety, and fathers' previous minimal involvement with the children increase mothers' reluctance to release children to their expartners’ care. This reluctance fits Hays’ (1996) notion of intensive mothering, a model of socially appropriate mothering that centers on women as central caregivers for their children. Hays found that many employed women do not relinquish childrearing responsibilities to their children's fathers because they believe men are poorly equipped to raise children. Hays was talking about the intensive mothering that occurs in first marriage families. It is no doubt intensified in the case of divorce. When mothers distrust ex-partners’ parenting abilities, coparenting relationships are unlikely to succeed.

Financial concerns are another factor affecting coparenting relationships. Lacroix (2006) found that sharing physical custody 50/50 reduces parents' likelihood of paying child support, which, in turn, reduces money related conflict. In this study, however, the women identified 
existing financial obligations. Even when child support is not ordered, former partners often share child-related expenses (e.g., childcare). In our study when fathers do not fulfill financial obligations, the coparenting relationship suffers.

Similar to Madden-Derdich, Leonard, and Christopher’s (1999) findings, in our study, relationship boundary ambiguity is related to conflictual coparenting relationships. Continuously contentious mothers report damaged coparenting relationships when ex-partners fixate on personal issues rather than focusing on the children. Coparenting also is damaged when expartners are controlling, similar to the findings of Kurz (1996). Although some continuously contentious women divorced because of intimate partner violence (IPV), divorce did not necessarily end abuse or controlling behavior. It is important to recognize that shared physical custody often puts women at risk for continued control or abuse (Hardesty \& Ganong, 2006).

Personal choice appears to be a key factor in coparenting relationships. Perhaps not surprisingly, mothers who did not want to share custody were most often in continuously contentious relationships. The question is raised about why mothers who do not want to share custody end up doing so. All but one initiated the divorce, and it appears that for some, as has been true in other studies (McKinnon \& Wallerstein, 1987), it is a matter of guilt or restitution for “causing” the divorce. Additionally, despite the evidence, women may optimistically believe they can put aside negative relationship issues and work cooperatively with their former partners. If so, this optimism would appear to be misguided.

Always amicable and continuously contentious groups do not appear to readily change perspectives, at least retrospectively. Their current attitudes toward shared custody are the same as they perceived they were at the time of the separation. Perhaps the most interesting group, therefore, is the bad to better. Although all of the women in this group describe their children's 
welfare as a factor in the improvement of their coparenting relationship, clear patterns as to how or why this improvement occurred, are not evident. Some can recall an event (e.g., death of a family member, restraining order) that sparked improvement, but for others, the change was ambiguous and gradual. For example, one mother who says she now focuses on her child and lets her anger go is unable to articulate why. It was obvious from interviews with these women that shared physical custody arrangements are dynamic, variable, and several positive and negative factors influence them. It is also clear that shared physical custody is a complex phenomenon.

\section{Theoretical Propositions}

The goal of this study was to produce a theory of divorced women’s experiences of sharing physical custody of their children with their former partner after divorce or separation. A coparenting typology was identified from these data. Based on our findings, several theoretical propositions can be made: (a) there is variability in the quality of coparenting relationships in shared physical custody arrangements; (b) cooperative coparenting relationships do not necessarily evolve from shared physical custody; (c) relationships between ex-partners are not static; (d) mothers and fathers can reduce coparenting conflict and improve ways of sharing custody by making conscious efforts to do so for their children's sake; and (e) mothers with cooperative coparenting relationships, unlike those with conflictual relationships, are able to communicate directly with ex-partners about the children, are not limited in the ways in which they exchange their children, and can effectively deal with differences in parenting styles.

\section{Implications}

This study highlights the need for practitioners to realize that coparenting relationships are dynamic. The typology identified can guide practitioners in tailoring advice to fit the needs of the various types of divorcing couples. Unfortunately, in many group interventions, such as 
divorce education programs, all parents hear the same message, which overlooks extremely variable dynamics. It is important for helping professionals to recognize that shared physical custody is not a panacea for post-divorce problems, and in some cases, it exacerbates it.

Although the continuously contentious and always amicable mothers' behaviors are more static, bad to better mothers originally allow their feelings about their ex-partner to interfere with coparenting. They eventually make a conscious effort, however, to improve their relationship for their children's sake. Instructors of divorced parent education programs need to emphasize the extreme importance of transitioning from spouse to coparent to help parents set aside negative feelings toward their ex-partners and focus on their children. Family life educators, in general, should be cautious about touting shared physical custody as the best choice for divorced family members, especially children. Rather the goal should be maintaining cooperative coparenting relationships that focus on the well-being of the child.

Some practical tips to help parents make this transition include suggesting conflictual parents communicate about their children by indirect means (e.g., email, texting), learn techniques for changing the topic from marital relationship problems to child related discussions, and talk with another person (e.g., friend, therapist) to get negative feelings about the ex-partner off their chest. Anger management programs may be appropriate for some divorcing spouses.

Coparents with continuously contentious relationships may benefit from additional information, especially those at high risk for IPV. Women in such relationships would benefit from safety-focused guidance (Hardesty \& Chung, 2006). These women also need to be guided in the development of boundaries. Focusing on the benefits of shared physical custody (e.g., children are able to have relationships with both parents) could improve or keep relationships positive for some couples, but that can be problematic when abuse or contentious relationships 
are a factor. If the ex-spouse is hostile and threatening, communication may need to be limited to texting and email messages, and exchanges in public places or through a third party may be necessary. Interventions could target factors identified by the mothers in this study as contributing to coparenting relationship quality (e.g., money issues).

Courts need to recognize that "women may be at risk if forced to share custody with their former husbands” (Hardesty \& Ganong, 2006, p. 544). If IPV contributed to the divorce, the expectation for former partners to cooperate in a shared physical custody arrangement may not be appropriate. Courts should require routine screenings for IPV. This is necessary because in our study, some women who reported that their ex-partners were abusive and/or controlling during the marriage still chose shared physical custody arrangements. The courts would be less likely to allow shared physical custody if there was evidence of abuse. Screening for IPV would reduce the likelihood of placing women and children at risk.

\section{Limitations and Suggestions for Future Research}

This study focuses on the experiences of a small sample of middle class, highly educated women who live in two Midwestern states. Participants were all White/European American women with the exception of one African American woman. Future investigations should seek a wider range of participants to increase our understanding of cultural and social influences on the process of shared physical custody.

Researchers could also investigate the role of new partners in shared physical custody arrangements. Although not the focus of our study, some of the women were either remarried or living with a new partner and/or their ex-partners had new partners. Some mothers found that exhusbands' new partners relieved some of the tension between the former partners, although 
others reported an increase in conflict when a new partner is introduced. The ways in which new relationships help or hinder coparental relationships between ex-partners should be explored.

It would be extremely helpful to study coparenting longitudinally, starting as soon after parental separation as possible. In our study, bad to better mothers were separated from their expartners for a slightly longer period of time ( $\mathrm{M}=3$ years) than were the continuously contentious ( $\mathrm{M}=2.25$ years). Although the time difference was not great, it may be that some continuously contentious relationships may improve in the future. There was little indication at the time of the interviews that improvement would happen, however, and there was no clear pattern of why the bad to better group improved. Longitudinal research should better enable us to distinguish what factors over time have the greatest influence on coparenting relationships.

Finally, this is a study of women's experiences of shared physical custody. Data from men who share physical custody would further contribute to theory-building as we have minimal understanding of fathers' feelings about sharing physical custody and how those feelings relate to their relationship with ex-partners. It is clear that the presence of certain negative factors increases the likelihood that mothers will have conflictual relationships with their ex-partners. Do the same factors influence fathers' perceptions of their coparenting relationships? For example, if fathers do not want to share physical custody, but the custody arrangement is decided by the court, will the relationship between the ex-partners be more conflictual? Or, would fathers view extra time with their children as positive?

It is evident from the women in this study that joint physical custody relationships are dynamic and varied. One must look at the relationship between the former partners and the ways in which they are sharing custody (i.e., communicating, dealing with parenting differences, and exchanging children) in order to understand the dynamics of these complex relationships. 


\section{References}

Arditti, J. A., \& Madden-Derdich, D. (1995). No regrets: Custodial mothers' accounts of the difficulties and benefits of divorce. Contemporary Family Therapy, 17, 229-248.

Bauserman, R. (2002). Child adjustment in joint-custody versus sole-custody arrangements: A meta-analytic review. Journal of Family Psychology, 16, 91-102.

Cancian, M., \& Meyer, D. R. (1998). Who gets custody? Demography, 35, 147-157.

Corbin, J., \& Strauss, A. (2008). Basics of qualitative research ( $3^{\text {rd }}$ edition). Thousand Oaks, CA: Sage.

Cork, D. L., \& Voss, P. R. (2006). Once, only once, and in the right place: Residence rules in the decennial census. Washington, DC: National Academies Press.

Demo, D. H., \& Fine, M. A. (2009). Beyond the average divorce. Thousand Oaks, CA: Sage.

Ellis, E. M. (2000). Divorce wars: Interventions with families in conflict. Washington, DC: American Psychological Association.

Elrod, L. D., \& Spector, R. G. (2011). A review of the year in family law: Working toward more uniformity in laws relating to families. Family Law Quarterly, 44, 469-518.

Hardesty, J. L., \& Chung, G. H. (2006). Intimate partner violence, parental divorce, and child custody: Directions for intervention and future research. Family Relations, 55, 200-210.

Hardesty, J. L., \& Ganong, L. H. (2006). How women make custody decisions and manage coparenting with abusive former husbands. Journal of Social and Personal Relationships, 23, 543-563.

Hays, S. (1996). The cultural contradictions of motherhood. New Haven, CT: Yale University. 
Hetherington, E. M., Cox, M., \& Cox, R. (1978). The aftermath of divorce. In J. H. Stevens, Jr., \& M. Matthews (Eds.), Mother-child, father-child relationships (pp. 149-176). Washington, DC: National Association for the Education of Young Children.

Johnston, J. R. (1995). Children’s adjustment in sole custody compared to joint custody families and principles for custody decision making. Family and Conciliation Courts Review, 33, $415-425$.

Juby, H., Le Bourdais, C., \& Marcil-Gratton, N. (2005). Sharing roles, sharing custody? Couples’ characteristics and children’s living arrangements at separation. Journal of Marriage and Family, 67, 157-172.

Kelly, J. B. (1994). The determination of child custody. The Future of Children, 4, 121-142.

Kim, H. K., \& McKenry, P. C. (2002). The relationship between marriage and psychological well-being: A longitudinal analysis. Journal of Family Issues, 23, 885-911.

Kreider, R.M. (2007). Living arrangements of children: 2004. Current Population Reports, P70114. Washington, DC: U.S. Census Bureau.

Kurz, D. (1996). Separation, divorce, and woman abuse. Violence Against Women, 2, 63-81.

Lacroix, C. (2006). Freedom, desire and power: Gender processes and presumptions of shared care and responsibility after parental separation. Women's Studies International Forum, 29, 184-196.

Maccoby, E. E., Buchanan, C. M., Mnookin, R. H., \& Dornbusch, S. M. (1993). Postdivorce roles of mothers and fathers in the lives of their children. Journal of Family Psychology, 7, 24-38.

Maccoby, E. E., Depner, C. E., \& Mnookin, R. H. (1990). Coparenting in the second year after divorce. Journal of Marriage and the Family, 52, 141-155. 
Madden-Derdich, D. A., Leonard, S. A., \& Christopher, F. S. (1999). Boundary ambiguity and coparental conflict after divorce: An empirical test of a family systems model of the divorce process. Journal of Marriage and the Family, 61, 588-598.

Markham, M. S., Ganong, L., \& Coleman, M. (2007). Coparental identity and mothers’ cooperation in coparental relationships. Family Relations, 56, 369-377.

McKinnon, R., \& Wallerstein, J. S. (1987). Joint custody and the preschool child. Behavioral Sciences \& the Law, 4, 169-183.

Melli, M. S., Brown, P. R., \& Cancian, M. (1997). Child custody in a changing world: A study of postdivorce arrangements in Wisconsin. University of Illinois Law Review, 3, 773-800.

Minton, C., \& Pasley, K. (1996). Fathers’ parenting role identity and father involvement: A comparison of nondivorced and divorced, nonresident fathers. Journal of Family Issues, 17, 26-45.

Mnookin, R., \& Kornhauser, L. (1979). Bargaining in the shadow of the law: The case of divorce. Yale Law Journal, 88, 950-997.

National Center for Health Statistics. (2002). Cohabitation, marriage, divorce, and remarriage in the United States. Vital Health Statistics, 23, 1-93.

Pearson, J., \& Thoennes, N. (1990). Custody after divorce: Demographic and attitudinal patterns. American Journal of Orthopsychiatry, 60, 233-248.

Pruett, M. K., \& Hoganbruen, K. (1998). Joint custody and shared parenting. Child and Adolescent Psychiatric Clinics of North America, 7, 273-294.

Sayer, L. C. (2006). Economic aspects of divorce and relationship dissolution. In M. A. Fine \& J. H. Harvey (Eds.), Handbook of divorce and relationship dissolution. (pp. 385-406). Mahwah, NJ: Erlbaum. 
Shiller, V. M. (1986). Joint versus maternal custody for families with latency age boys: Parent characteristics and child adjustment. American Journal of Orthopsychiatry, 56, 486-489.

Steinman, S. (1981). The experience of children in a joint-custody arrangement: A report of a study. American Journal of Orthopsychiatry, 51, 403-414.

Tejada-Vera, B., \& Sutton, P. D. (2010). Births, marriages, divorce, and deaths: Provisional data for 2009. National Vital Statistics Reports, 58, 1-6.

Wallerstein, J. S., \& Kelly, J. B. (1980). Effects of divorce on the visiting father-child relationship. American Journal of Psychiatry, 137, 1534-1539. 
Table 1.

Summary of Participants' Characteristics

\begin{tabular}{|c|c|c|c|c|c|c|c|c|}
\hline \# & Age & Yrs. Partner & Yrs. Separated & Child Sex/Age $^{\mathrm{a}}$ & \% Custody & Repartnered & Ex Repartnered & Type $^{b}$ \\
\hline 1 & 26 & 8 & 1.5 & $F(4)$ & $60 \%$ & No & No & $\mathrm{BB}$ \\
\hline 2 & 28 & 7 & 0.5 & M (21 months) & $57 \%$ & No & No & AA \\
\hline 3 & 28 & 6 & 3 & F (3) & $50 \%$ & Yes & No & $\mathrm{CC}$ \\
\hline 4 & 28 & 3 & 4 & $\mathrm{M}(8), \mathrm{F}(6)$ & $57 \%$ & No & No & $\mathrm{BB}$ \\
\hline 5 & 30 & 4 & 2.5 & $F(6), M(5)$ & $43 \%$ & No & No & $\mathrm{BB}$ \\
\hline 6 & 30 & 4 & 4.5 & $F(9), M(6)$ & $64 \%$ & No & No & $\mathrm{CC}$ \\
\hline 7 & 30 & 4 & 12 & F (12) & $50 \%$ & Yes & Yes & AA \\
\hline 8 & 31 & 5 & 1 & M (6), M (3) & $64 \%$ & No & No & $\mathrm{CC}$ \\
\hline 9 & 31 & 5 & 1.5 & M (6), M (3) & $50 \%$ & No & No & $\mathrm{BB}$ \\
\hline 10 & 32 & 7 & 3 & $F(5)$ & $50 \%$ & No & Yes & $\mathrm{BB}$ \\
\hline 11 & 32 & 6.5 & 5 & F (7) & $64 \%$ & No & Yes & AA \\
\hline 12 & 32 & 7 & 2 & $\mathrm{~F}(9), \mathrm{M}(7), \mathrm{F}(4)$ & $57 \%$ & No & No & CC \\
\hline
\end{tabular}


Table 1.

Summary of Participants' Characteristics

\begin{tabular}{|c|c|c|c|c|c|c|c|c|}
\hline \# & Age & Yrs. Partner & Yrs. Separated & Child Sex/Age ${ }^{a}$ & \% Custody & Repartnered & Ex Repartnered & Type $^{\mathrm{b}}$ \\
\hline 13 & 33 & 7 & 2.5 & $\mathrm{M}(9), \mathrm{F}(6)$ & $50 \%$ & No & Yes & $\mathrm{BB}$ \\
\hline 14 & 34 & 12 & 1.5 & $\mathrm{~F}(7)$ & $50 \%$ & No & No & CC \\
\hline 15 & 36 & 8 & 6 & M (9) & $50 \%$ & Yes & No & $\mathrm{BB}$ \\
\hline 16 & 36 & 12 & 3 & $\mathrm{~F}(11)$ & $50 \%$ & No & Yes & CC \\
\hline 17 & 43 & 6 & 1.5 & $\mathrm{M}(5)$ & $57 \%$ & No & No & AA \\
\hline 18 & 43 & 17 & 1.25 & $\mathrm{~F}(10)$ & $50 \%$ & No & Yes & CC \\
\hline 19 & 45 & 7 & 1 & $F(6), F(4)$ & $50 \%$ & No & No & $\mathrm{CC}$ \\
\hline 20 & 49 & 2 & 3 & M (4) & $57 \%$ & No & No & CC \\
\hline
\end{tabular}

${ }^{\mathrm{a}}$ Child Sex; $\mathrm{M}=$ male, $\mathrm{F}$ = female;

$\mathrm{b}$ Type; $\mathrm{AA}=$ always amicable, $\mathrm{BB}=$ bad to better, $\mathrm{CC}=$ continuously contentious 
Figure 1

A Proposed Model of Mothers' Perceptions of Sharing Physical Custody after Separation or Divorce

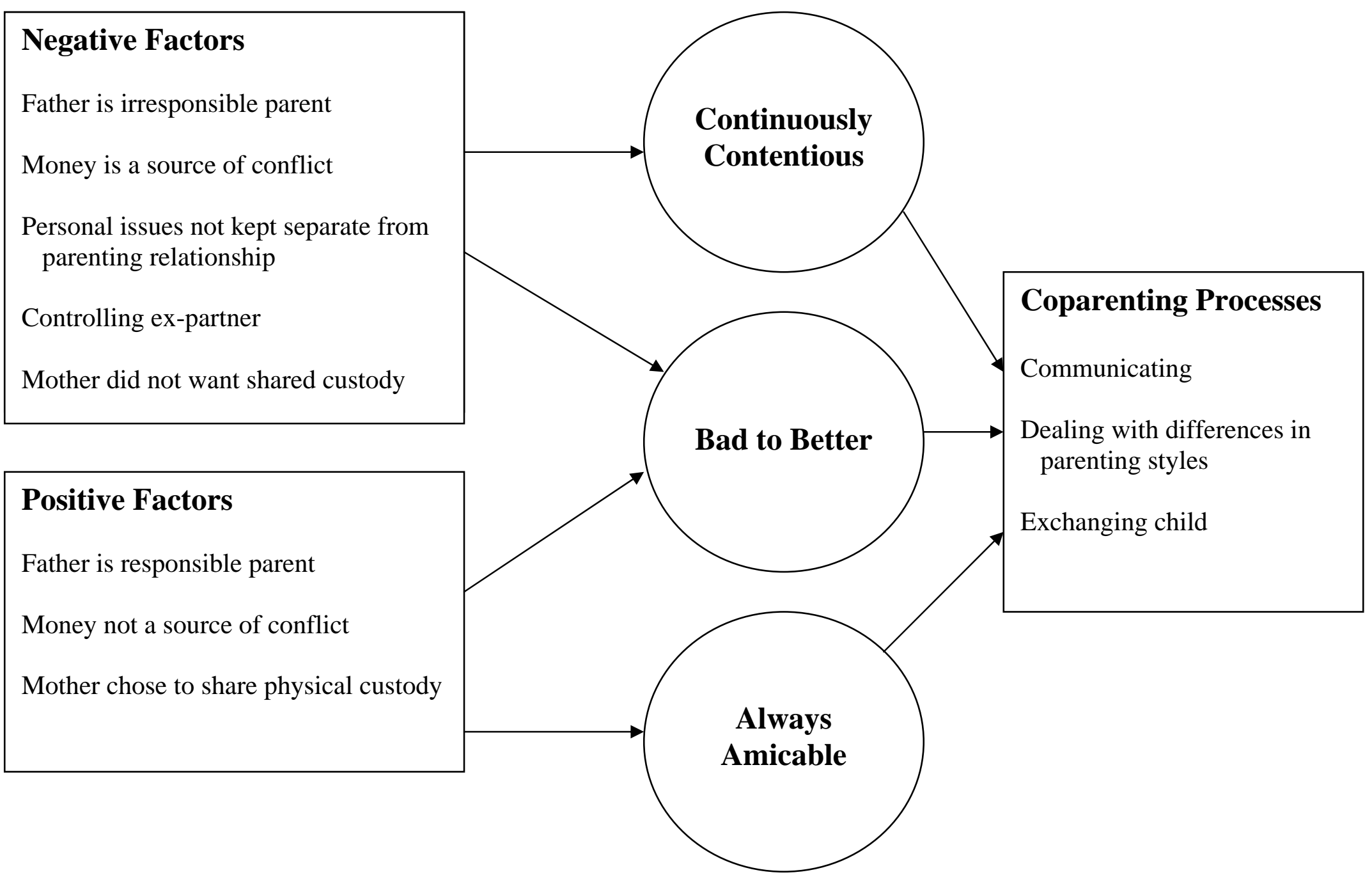

